\title{
Does Local Governments' Budget Deficit Push Up Housing Prices in China?
}

\section{Guiying Laura WU, Qu FENG and Pei LI}

\author{
12 August 2014 \\ EGC Report No: 2014/09
}

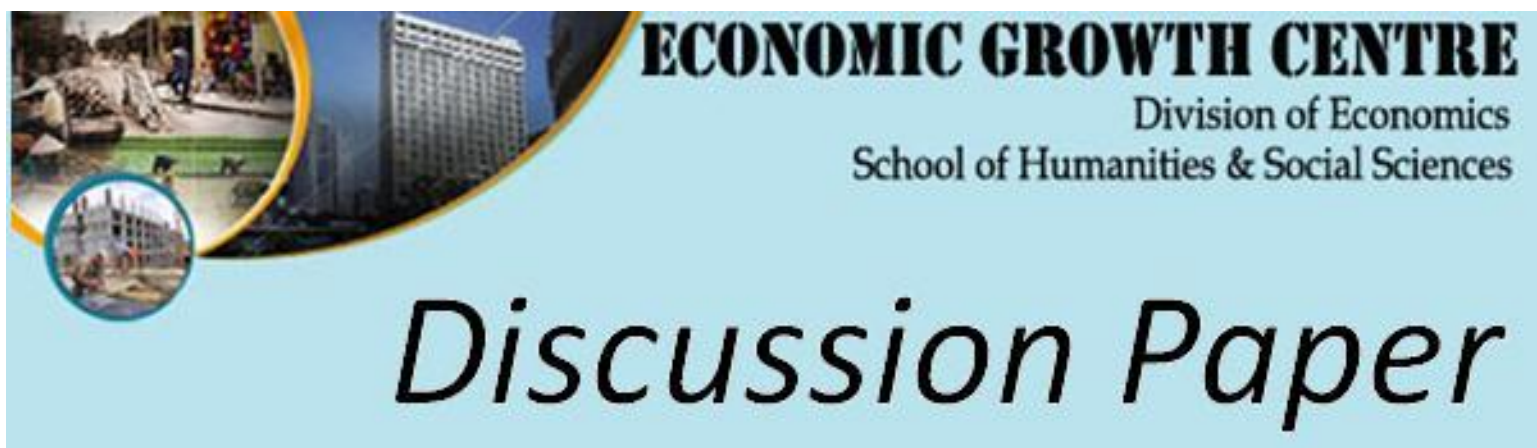


The author(s) bear sole responsibility for this paper.

Views expressed in this paper are those of the author(s) and not necessarily those of the Economic Growth Centre, NTU. 


\title{
Does Local Governments' Budget Deficit Push Up Housing Prices in China?*
}

\author{
Guiying Laura Wu$\dagger$ Qu Feng ${ }^{\ddagger}$ and Pei $\mathrm{Li}^{\S}$
}

August 12, 2014

\begin{abstract}
Budget deficit has been a common fiscal pressure facing Chinese cities since the 1994 fiscal reform. Meanwhile, land lease sales have become a significant off-budgetary revenue to local governments since 2003. This paper investigates whether financing budget deficit is an important driving force of the recent soaring housing prices when local governments function as the monopoly supplier of urban land. A conceptual framework is developed to illustrate a transmission mechanism from budget deficit to housing prices. This leads to an empirical model consisting of two simultaneous structural equations for housing prices and land prices. Using data for the 35 major Chinese cities from 2003 to 2011, an empirical exercise shows although budget deficit has a positive effect on land prices, it is the factors from demand side, such as amenities, income and the user cost of housing capital, that have been pulling up the housing prices.
\end{abstract}

JEL Classification: R21, R31, H27, G10

Key Words: Housing Prices, Land Prices, Public Finance, Chinese Economy

${ }^{*}$ We would like to thank Josef Brada, Yuming Fu, Jan F. Kiviet, Zonglai Kou, Zhigang Li, YewKwang Ng, seminar participants at Nanyang Technological University, East Asian Institute at National University of Singapore, and audiences at TED conference 2013, Fudan University, for their constructive comments and suggestions. Financial support from the New Silk Road research grant at Nanyang Technological University is gratefully acknowledged.

${ }^{\dagger}$ Division of Economics, School of Humanities and Social Sciences, Nanyang Technological University. Address: 14 Nanyang Drive, Singapore, 637332. Email: guiying.wu@ntu.edu.sg.

†Division of Economics, School of Humanities and Social Sciences, Nanyang Technological University. Address: 14 Nanyang Drive, Singapore, 637332. Email: qfeng@ntu.edu.sg

§Institute of Real Estate Studies, National University of Singapore. Email: bengcome@gmail.com. 


\section{Introduction}

In the past decade major Chinese cities have been experiencing a surge of housing prices that is probably unprecedented in history. As illustrated in Figure 1, the average real residential housing prices in the 35 major Chinese cities have steadily increased from 2426 yuan per square meter in 2003 to 5937 yuan per square meter in $2011 .^{1}$ This implies an $11.8 \%$ real compound annual growth rate, which even dwarfs China's remarkable GDP growth rate during the same period. Such rampant housing price growth has aroused great interest and concern on its causes and consequences.

Among many alternative explanations, a public finance perspective has been attracting more and more attention among media, researchers and policy makers. Although different people may frame their hypotheses in various ways, a common feature of this perspective is to attribute the soaring housing prices to the high reliance of local governments on land sales revenue to finance their budget deficit. Three stylized facts have been widely cited to support this conjecture. First, recent years have witnessed a significant increase in land prices. According to Figure 2, although there is a temporary decline in 2008, the average real land prices of the 35 cities have almost doubled over the eight years. Second, budget deficit is a common fiscal pressure facing many local governments. Figure 3 plots the shares of budgetary deficit and land transferring fee to budgetary revenue of the 35 major cities from 2003 to 2011. In aggregate these major Chinese cities have been constantly running a budgetary deficit. On average the deficit accounts for as much as $26 \%$ of the revenue. Finally, land transferring fee is becoming an important off-budgetary revenue to local governments. According to Figure 3, averaging across cities the land transferring fee reaches $57 \%$ of the revenue and in some years this ratio even exceeds $70 \%$. It is not surprising that a new terminology "land finance" has been created and frequently appears in the title of news reports, research papers and policy discussion.

Although the conjecture that links housing prices to budget deficit has been popular for a while, this is probably the first paper that formally tests whether the local governments' budget deficit is indeed a driving force of the recent soaring housing prices. The answer to this question is important for at least two reasons. First, it has immediate policy implications. The accumulation of local budget deficit and inflation of housing prices are two urgent challenges facing policy makers in China. If local budget deficit indeed has a causal effect on housing price growth, a reform in public finance might be more pertinent than price regulations in curbing housing price inflation. ${ }^{2}$ On the other hand, if housing price appreciation has a causal effect on land

\footnotetext{
${ }^{1}$ These 35 cities represent all municipalities, provincial capital cities and quasi-provincial capital cities in China, whose housing prices have been closely watched.

${ }^{2}$ The State Council, China's top policy-making body, has implemented a series of housing price
} 
price appreciation, given the significant role of land transferring fee in making up for the local budget deficit, a large enough drop in housing prices could potentially lead to a local fiscal crisis. Second, the answer to this research question also has general theoretical values. What to spend and how a government finances its expenditure are the central themes of public finance. In most advanced economies, local governments spend money in providing local public services, which enhance the local public amenities and are capitalized into housing prices. Such expenditure is financed from property tax, which increases with housing values. Local governments in China are also the provider of local public services but have to finance the expenditure from land lease sales instead of property tax. This unique feature offers an interesting case to study the role of public finance on resource allocation and asset price.

This paper is closely related to two streams of the literature on China's housing prices. The first tries to explain the price growth by examining the determinants of demand and supply for housing, such as Liang and Gao (2007), Chow and Niu (2010), Zhou (2011) and Garriga, Tang and Wang (2013), and questions whether the housing price has substantially deviated from its fundamental value, such as Ren, Xiong and Yuan (2012), Wu, Gyourko and Deng (2012) and Wang and Zhang (2013). The second stream focuses on micro evidences from land market and studies the determinants of land auction price. Leading examples include Deng, Morck, Wu and Yeung (2011) and Cai, Henderson and Zhang (2012).

Inspired by these existing researches, this paper provides a conceptual framework for the transmission mechanism from budget deficit to housing prices, by explicitly modeling the interrelationship between housing prices and land prices. This leads to a system with two simultaneous structural equations for housing prices and land prices. A panel data set of the 35 cities that is publicly available from 2003 to 2011 is employed to estimate the model. Under a set of alternative endogeneity assumptions, a robust finding is the importance of the demand side factors on pulling up the housing prices. Although budget deficit does have a positive effect on land prices, land prices have limited contribution to the surging housing prices. In contrast, housing prices are the most important determinant for land prices. This implies that the increase in housing prices has been the cause rather than the consequence of the increasing land prices.

The rest of the paper is organized as follows. Section 2 first introduces the institutional background that is necessary to appreciate the logic behind the hypothesis. Section 3 describes the theoretical framework. Section 4 explains the data and reports the empirical findings. Section 5 discusses the implications and limitations.

control policies via administrative orders since 2003. The well-known examples include the "Eight Measures" in March 2005, the "Six Measures" in 2006, the "Quantity Quota" in January 2011 and the "New Five Measures" in March 2013. 


\section{Institutional Background}

\subsection{The Housing Market and Land Market}

The housing market reform in China was far lagged behind its general economic reform. Before 1998, most employees lived in housing provided by their work units with a highly subsidized rent. In 1998 the State Council formally abolished this welfare-based public housing system by decree. From then on, employees get housing benefits in cash from their employers and have to buy or rent residential housing in the private market. The return of the desire for homeownership after decades of suppression during the socialist era leads to a significant increase in housing prices (Wang, 2011).

The development of land market in China was further lagged behind its housing market. By law, the state has the ultimate ownership of all land. Any individual or organization has to apply for permission from the government in construction on any land. In practice, the local governments function as the monopoly supplier of urban land. In a typical case of development, a local government first converts a parcel of agriculture land at the suburban periphery into urban land by compensating farmers who work and live on it. The local government then sells the land use right to a developer in exchange for a land transferring fee. The developer builds private housing units on the parcel and subsequently sell the units to individual households. Households have the right to live in, rent out and resell their housing during the leasehold period, which is 70 years for residential housing.

Before 2003, the land use right was usually not publicly transacted. Instead, when a developer was interested in a particular land parcel, it would approach the government and negotiate a price for it. This process has been criticized for being subject to possible bribe and corruption and results in a land price below market value. In April 2001 the State Council announced the reform for land market by emphasizing the importance of market force in land allocation. In May 2002 the Ministry of Land and Resources required all residential and commercial land parcel leaseholds subsequent to July 2002 to be sold via public auctions. Currently, all transactions must be via either regular English auction (paimai), two-stage auction (guapai) or sealed-bid auction (zhaobiao). Cai, Henderson and Zhang (2012) examine the effect of different auctions on the resulting land prices.

\subsection{The Fiscal Reforms and Budget Deficit}

The total revenue of Chinese local governments is made of three components: budgetary revenue (yusuan nei shouru), extra-budgetary revenue (yusuan wai shouru) and non-budgetary revenue (fei yusuan shouru). The budgetary revenue includes both revenue from all sorts of taxes, and non-tax revenue such as special program receipts and 
penalty receipts. The extra-budgetary revenue refers to financial fund of various types not covered by the regular government budgetary management, which is collected and allocated by local governments in accordance with laws, rules and regulations. It mainly covers administrative and institutional fees, revenue of government funds, and self-raised and collected funds by township governments for their own expenditure. All other funds fall into the category of non-budgetary revenue. Information on budgetary revenue is available at the city level. Information on extra-budgetary revenue is only reported at the provincial level. Data on non-budgetary revenue is not publicly available. For this reason, the sum of extra-budgetary revenue and non-budgetary revenue is sometimes referred to as the off-budgetary revenue (fei yusuan nei shouru).

The current fiscal system in China was established in 1994, when the State Council introduced the "tax sharing reform" to arrest the decline in central fiscal revenue. The reform required the local governments to submit a substantial proportion of their tax revenue to the central government. For example, before the reform, value-added tax, the most important source of tax revenue, was equally shared between the local and central governments. But the reform left the local governments with only $25 \%$ of the value-added tax. Some additional adjustments taking place in later years further clawed back tax revenue from local governments. For example, the central government and local governments equally shared the stamp tax on security exchange before 1997, but the local governments can only keep $20 \%$ since 1997 and $3 \%$ since 2000 . In 2002, half of the enterprise income tax and personal income tax, which previously belonged solely to the local governments, had to be submitted to the central government. This proportion further increased to $60 \%$ in 2003.

While the local budgetary revenue declined, the fiscal responsibilities of the local governments did not. Table 1 reports several important ratios calculated using aggregate data for all local governments in China. As shown in Columns 1 and 2, before 1994, the share of local budgetary revenue to national budgetary revenue was very close to that of expenditure. After 1994, the share of revenue suddenly dropped from $78 \%$ to $44 \%$ and remained around $47 \%$ in later years, while the share of expenditure steadily increased from $70 \%$ to $85 \%$ in recent years. Consequently, the local governments have been running a constant budgetary deficit since 1994. Column 4 indicates that the magnitude of the deficit has been gradually increasing and reaches $8.5 \%$ of GDP in 2011.

The increasing gap between expenditure and revenue rendered local governments to enthusiastically pursue various extra-budgetary funds, which they generally got to keep. As a result, the ratio of local governments extra-budgetary revenue to budgetary revenue suddenly increased from $35 \%$ in 1993 to $68 \%$ in 1994 . The pervasive presence of extra-budgetary funds caused increasing concern of the central government. Since 
1997, the central government had launched several rounds of large-scale investigations on extra-budgetary revenue and gradually implemented the reform entitled "separate management of income and expenditure" (shouzhi liangtiao xian) that subjected extrabudgetary revenue to more stringent monitoring. As a result, the ratio of local extrabudgetary to budgetary revenue steadily shrunk from $79 \%$ in 1998 to $13 \%$ in 2010 . This explains the inverted U-shaped ratios reported in Column 3. The budget reform in 2011 generally brought all extra-budgetary activities back into the budget. As indicated in Column 5, although surplus from extra-budgetary account could partially compensate the deficit from the budgetary account, as a consequence of the extra-budgetary reform, the top-up role of extra-budgetary surplus has been ever diminishing and negligible.

As a compensation to local governments for the losses from a series of fiscal reforms, massive land conversion and development throughout the country was tacitly considered as a legitimate source for "topping up" local public expenditures (Cai, Henderson and Zhang, 2012; Jia, Guo and Zhang, 2014). Consequently, many local governments began to keenly engage in promoting urbanization (Kung, Xu and Zhou, 2011). Rapid urbanization helps spur local GDP growth, which in turn enhances the career prospects of local officials (Xu, 2011).

As highlighted in Column 6, revenue from land transferring fee is becoming a more and more important source of off-budgetary local revenue. There is indeed a sudden jump in the ratio of land transferring fee to local budgetary revenue in 2003, when all land leaseholds must be transacted via public auctions. Column 7 reports the provincial Gini coefficient of this ratio. The obvious decrease in the Gini coefficient suggests that more and more local governments exercise their monopoly power in land supply and grasp huge windfall via land sales.

\section{Budget Deficit and Housing Prices: A Frame- work}

Taking into account the interesting China specific background, this section derives a conceptual framework in which housing prices and land prices are simultaneously determined through the interaction of households, developers and local governments in the two related markets. Specifically, in housing market, the equilibrium housing price level is determined by housing demand and housing supply derived from the behavior of households and developers, respectively. In land market, the demand from developers and the monopoly supply from local government yield the equilibrium land price level. The model consisting of housing price and land price equations serves as a theoretical guider for the empirical exercises in Section 4.

This model shares three common features with the literature. First, as predicted 
by the monocentric city model such as Mills (1967), this model also implies an increase in income and population will lead to an increase in the land and housing prices of the city. Second, it follows the asset approach such as Poterba (1984) and Himmelberg, Mayer and Sinai (2005), in deriving the equilibrium condition for households' tenure choice. Finally, it examines the role of local governments on the values of housing and land from a public finance perspective pioneered by Tiebout (1956) and Oats (1969).

\subsection{Households}

The preferences of a representative household living in a city are captured by the utility function $U=U(a, g, \gamma, x)$. Here $a$ is the exogenous amenities of a city, such as clean air. $g$ represents local public amenities that enhance the quality of life. $\gamma$ is the units of housing space that the household has rent. $x$ stands for a bundle of private goods whose price is normalized to unity. Suppose the rent is $r$ per unit. This implies each household consumes housing service, either as a tenant renting from landlords, or as a home owner effectively renting to itself. Denote the disposable income of the household as $y$. Utility maximization subject to the income budget constraint $r \gamma+x=y$ leads to an optimal demand for rent given by function $\gamma=\gamma(r, a, g, y)$. For a city with $N$ homogeneous households, the aggregate demand function for rent is therefore

$$
R^{d} \equiv N \gamma=R^{d}(r, a, g, y, N)
$$

where $\frac{\partial R^{d}}{\partial r}<0, \frac{\partial R^{d}}{\partial a}>0, \frac{\partial R^{d}}{\partial g}>0, \frac{\partial R^{d}}{\partial y}>0$ and $\frac{\partial R^{d}}{\partial N}>0$ under regularity conditions on $U$.

Aggregate rent supply $R^{s}$ depends on housing stock $H_{0}$, i.e., $R^{s}=R^{s}\left(H_{0}\right)$. Equilibrium condition $R^{d}=R^{s}$ in the rent market implies that equilibrium rent is a function of demand-side factors and $H_{0}$ :

$$
r=r\left(a, g, y, N, H_{0}\right) .
$$

Housing demand decision for a representative household comes from the comparison between the housing price $p$ and the present value of rent, $\frac{r}{u c}$, where $u c$ represents the user cost of housing capital. This implies that the household's demand for housing is equal to $1\left\{p \leq \frac{r}{u c}\right\}$, where $1\{\cdot\}$ is the indicator function. Thus, the aggregate housing demand $H^{d}$ is a function of $p, r, u c$ and $N$, i.e., $H^{d}=f(p, r, u c, N)$, where $\frac{\partial f}{\partial p}<0$, $\frac{\partial f}{\partial r}>0, \frac{\partial f}{\partial u c}<0, \frac{\partial f}{\partial N}>0$. Substituting (2) in $H^{d}$ gives aggregate housing demand function as

$$
H^{d}=H^{d}\left(p, a, g, y, N, u c, H_{0}\right)
$$

where $\frac{\partial H^{d}}{\partial p}<0, \frac{\partial H^{d}}{\partial a}>0, \frac{\partial H^{d}}{\partial g}>0, \frac{\partial H^{d}}{\partial y}>0, \frac{\partial H^{d}}{\partial N}>0$, and $\frac{\partial H^{d}}{\partial u c}<0$.

The user cost is defined as $\delta+\kappa+\alpha+i-\pi-\pi^{Q}$. Here $\delta$ stands for depreciation rate, $\kappa$ for maintenance cost, $\alpha$ for risk premium of housing capital relative to safe assets, 
$i$ for nominal interest rate, $\pi$ for overall inflation rate, and $\pi^{Q}$ for real housing price inflation rate. ${ }^{3}$ To accommodate the status competition hypothesis of Wei, Zhang and Liu (2010), an ownership premium, similar to risk premium but working in the opposite direction, is allowed in the user cost. It implies that the rise in housing prices is not driven by an actual demand for housing, but by the demand for owning a house itself. This ownership premium is measured by the sex ratio $s$, as a proxy for the intensity of status competition. This leads to an augmented user cost of housing capital under China's context as

$$
u c=\delta+\kappa+\alpha+i-\pi-\pi^{Q}-s .
$$

\subsection{Developers}

Property developers are simultaneously on the supply side of housing market and demand side of land market. Under the assumption of free entry they are price takers in both markets. Suppose developers use the production technology $H=F(L)$ to transform a land parcel of size $L$ into housing $H$, where $F^{\prime}(L)>0$ and $F^{\prime \prime}(L)<0$. The profit function is therefore given by $p F(L)-L(l+c)-c_{0}$, where $l$ is the unit land price that the developers have bid to obtain the land and $c$ is a unit composite cost of construction. $c_{0}$ is a fixed cost for zero profit condition. The first order condition of profit maximization then leads to the demand function for land

$$
L^{d}=L^{d}(l, p, c)
$$

where $\frac{\partial L^{d}}{\partial l}<0, \frac{\partial L^{d}}{\partial p}>0$, and $\frac{\partial L^{d}}{\partial c}<0$.

It also implies that the supply function of housing is given by

$$
H^{s}=F\left(L^{d}\right)=H^{s}(l, p, c)
$$

where $\frac{\partial H^{s}}{\partial l}<0, \frac{\partial H^{s}}{\partial p}>0$, and $\frac{\partial H^{s}}{\partial c}<0$.

\subsection{Local Government}

The institutional background introduced in Section 2.1 implies that the local government is the monopoly supplier of urban land. As described in Section 2.2, to meet the large and increasing gap between expenditure and revenue, the local government

\footnotetext{
${ }^{3}$ In Poterba's $(1984,1991)$ original work in the context of the U.S., the user cost is determined by $u c=\delta+\kappa+\alpha+(1-\theta)(i+\mu)-\pi-\pi^{Q}$.

where $\theta$ stands for marginal income tax rate, $\mu$ for property tax rate. Given there is no general property tax and mortgage interest is not tax deductible in China, we assume $\theta=\mu=0$ here.
} 
supplies $L^{s}$ units of urban land so as to balance the deficit $d$ with the net revenue from land leasing:

$$
l L^{s}-C\left(A, L_{0}, L^{s}\right)=d .
$$

$C\left(A, L_{0}, L^{s}\right)$ is the cost of land supply. Suppose farmers are fairly compensated when the local government levies agriculture land and converts it into urban land for property development. ${ }^{4}$ Then the cost of supplying urban land is determined by the revenue of agriculture land, which depends on $A$, the agriculture productivity, and $L_{0}-L^{s}$, the difference between total available land for either agriculture production or residence, and urban land supply. Equation (6) gives the land supply as a function of budget deficit:

$$
L^{s}=L^{s}\left(l, d, A, L_{0}\right)
$$

\subsection{Equilibrium Housing and Land Prices}

When the housing market is at equilibrium, $H^{d}=H^{s}$. An equilibrium housing price level $p$ can be derived by equating equation (3) with (5):

$$
p=p\left(l, a, g, y, N, u c, c, H_{0}\right),
$$

where $\frac{\partial p}{\partial a}>0, \frac{\partial p}{\partial g}>0, \frac{\partial p}{\partial y}>0, \frac{\partial p}{\partial N}>0, \frac{\partial p}{\partial u c}<0, \frac{\partial p}{\partial l}>0$, and $\frac{\partial p}{\partial c}>0$.

When the land market is at equilibrium, $L^{d}=L^{s}$. Equating equation (4) with (7) leads to the equilibrium land price level:

$$
l=l\left(p, d, c, A, L_{0}\right)
$$

where $\frac{\partial l}{\partial p}>0, \frac{\partial l}{\partial c}<0, \frac{\partial l}{\partial A}>0$, and $\frac{\partial l}{\partial L_{0}}<0$. Since an increase in budget deficit may lead to an increase in land sales or an increase in land price, the sign of $\frac{\partial l}{\partial d}$ is ambiguous. It depends on the price elasticity of land demand, which is fundamentally determined by the construction technology $F$; and the marginal cost of urban land supply, which is in effect regulated by the function form of the agriculture revenue. ${ }^{5}$

The system of two simultaneous equations (8) and (9) characterizes a possible transmission mechanism from budget deficit $d$ to housing price $p$. Although land price $l$ has an unambiguous positive effect on housing price $p$, the model predicts an ambiguous effect of budget deficit $d$ on land price $l$, which leaves the effect of budget deficit $d$ on housing price $p$ an empirical question.

\footnotetext{
${ }^{4}$ According to some anecdote news, local governments could underestimate the land acquisition compensation for farmers to boost revenue. However, since the compensation data is not available, it is not possible to test this potential mechanism. That is why we maintain the fair compensation assumption in the model.

${ }^{5}$ Equations (8) and (9) characterize the determinants of equilibrium housing price and land price while the equilibrium quantities of housing and land have been solved out. For those who are interested in what factors explain floor space sold and volume of land transacted, please refer to Deng et al. (2012).
} 
The model has been explicit about the endogenous relationship between $p$ and $l$ in the two related markets and treats all other variables as exogenous. If households have perfect mobility as assumed in Tiebout (1956), when they shop among different cities and select as residents of the city which offers the housing price-and-public service package best suited to their preferences, both local public amenity $g$ and budget deficit $d$ would be endogenous. In a more general setting with an open system of cities, such as Albouy (2009), both income level $y$ and population size $N$ would also be endogenous. For simplicity, the theoretical framework is restricted only to the case of exogeneity. But the empirical section does test the importance of allowing for potential endogeneity of $g, d, y$ and $N$.

\section{Empirical Exercises}

This section evaluates the effect of budget deficit on housing prices by estimating the model using a panel data set of the 35 major Chinese cities from 2003 to 2011. The sample period starts from 2003 when market force started to play a key role in the land lease sales and ends at 2011 when the most recent data are available.

We assume that equations (8) and (9) are linear and stochastic. They can be represented by the following model for estimation:

$$
\begin{aligned}
p_{i t}= & \alpha_{0}+\alpha_{1} l_{i t}+\alpha_{2} a_{i t}+\alpha_{3} g_{i t}+\alpha_{4} y_{i t}+\alpha_{5} N_{i t} \\
& +\alpha_{6} s_{i t}+\alpha_{7} i_{t}+\alpha_{8} \pi_{i t}+\alpha_{9} \pi_{i t}^{Q}+\alpha_{10} c_{i t}+u_{i}^{p}+v_{i t}^{p}
\end{aligned}
$$

and

$$
l_{i t}=\beta_{0}+\beta_{1} p_{i t}+\beta_{2} d_{i, t-1}+\beta_{3} c_{i t}+\beta_{4} A_{i t}+\beta_{5} L_{0, i t}+u_{i}^{l}+v_{i t}^{l},
$$

where $u_{i}^{p}$ and $u_{i}^{l}$ are unobservable city specific effects; $v_{i t}^{p}$ and $v_{i t}^{l}$ are error terms. Due to lack of data on $\delta, \kappa, \alpha$ in user cost $u c$ and on housing stock $H_{0}$, these variables are absorbed by $u_{i}^{p}$ and $v_{i t}^{p}$ in (10). Since these two structural equations are derived from behavioral models, their coefficients have causal interpretation. For example, though $p_{i t}$ and $l_{i t}$ are interdependent, $\alpha_{1}$ in equation (10) measures the causal effect of land price on housing price. Similarly, $\beta_{2}$ in equation (11) gives the causal effect of budget deficit on land price. In addition, these two structural equations also indicate that budget deficit has no direct effect on housing price, but it affects housing price via land price. To address the potential concern of the endogeneity of budget deficit, a lagged value of budget deficit, $d_{i, t-1}$, is included in the land price equation (11).

By substituting equation (11) into (10), these two structural equations give a reduced-form equation for housing price:

$$
\begin{aligned}
p_{i t}= & \theta_{0}+\theta_{1} d_{i, t-1}+\theta_{2} a_{i t}+\theta_{3} g_{i t}+\theta_{4} y_{i t}+\theta_{5} N_{i t}+\theta_{6} s_{i t}+\theta_{7} i_{t} \\
& +\theta_{8} \pi_{i t}+\theta_{9} \pi_{i t}^{Q}+\theta_{10} c_{i t}+\theta_{11} A_{i t}+\theta_{12} L_{0, i t}+u_{i}+v_{i t},
\end{aligned}
$$


where $u_{i}$ and $v_{i t}$ are the unobservable city specific effects and the error term, respectively. The coefficients in this reduced-form regression measure the overall effects of the corresponding variables on housing price. For example, $\theta_{4}$ is the total effect of income on housing prices. In the reduced-form equation, no mechanism is specified how income affects housing price, so $\theta_{4}$ has different interpretation from the structural parameter $\alpha_{4}$ in equation (10). Note that $\theta_{1}$ measures the indirect effect of budget deficit on housing price. The omitted land price serves as a transmission channel, which is affected by budget deficit and contributes to housing price dynamics.

\subsection{Data and Variables}

Data on housing price $p$ come from the China Real Estate Statistic Book, which reports the city average residential housing prices every year since 1998 but only for the 35 major cities. Data on land price $l$ are from the China Land and Resource Almanac, calculated as dividing the land transferring fee by land transferring area transacted via auctions. ${ }^{6}$ Ideally, both housing prices and land prices should be constructed to adjust for quality change, using either the repeated sales price indexes pioneered by Case and Shiller (1987), or more pertinently, the hedonic techniques for a nascent market like China as suggested by Wu, Deng and Liu (2013). Using city average housing and land prices certainly smooths out many within-city heterogeneities in the quality of housing units and land parcels. However, such construction needs information from micro-level data which are not publicly available even for these major Chinese cities and for very recent years.

The amenity of a city $a$ potentially has many measures, such as climate and geography. However, both of them are time-invariant. To identify the effect of amenity on housing price in a fixed-effects model, following Zheng, Kahn and Liu (2010) this paper adopts a time-varying measure of quality of air, namely the $\mathrm{SO}_{2}$ density reported in the City Statistic Yearbook. Local public expenditure is usually taken as the only feasible proxy for public output that determines the local public amenities $g$. Per capita government expenditure immediately suggested itself; however, it is not a satisfactory measure, given some variations in spending may have nothing to do with the level or quality of output. Following the literature in urban economics, such as Oates (1966), $g$ is measured by government expenditure on education per student. Both the numerator and denominator come from the China Statistic Yearbook for Regional Economy.

$y$ is proxied by urban disposable income per capita reported in the China Statistic Yearbook for Regional Economy. $N$ is measured by total population, which is collected from the statistic yearbooks for each province and municipality. Total population is the

\footnotetext{
${ }^{6}$ Since land for industrial use is usually directly allocated by local governments, the prices calculated in this way mainly reflect the value for residential and commercial land.
} 
sum of local residents with hukou and migrants without hukou but live in the city for more than six months of the year. Large scale rural-to-urban migration has been taking place in China as a result of massive industrialization and urbanization, while these major cities are the main destination of the migrants. These new migrants contribute to the housing demand, either directly through purchase or indirectly through renting.

As for the components of user cost, the data on male-to-female sex ratio $s$ are from the Statistics of City and County Demographic. The 5-year nominal interest rate of deposit serves as a good measure for $i$. It is common across all the cities but is very volatile over the sample period. As usual, the growth rate of CPI is taken as a measure for the overall inflation rate $\pi$.

The key challenge lies in the measurement for $\pi^{Q}$, the expected real housing price appreciation, since households' expectation is not observable. Both the classical survey for the U.S. (Case and Shiller, 1988) and the empirical evidence for China (Kuang, 2010) suggest that most households seem to set price expectation with a backwardlooking process. Therefore, this paper measures $\pi^{Q}$ by the growth rate of real housing prices in the previous year in the benchmark specification. The empirical exercise also allows for a more flexible treatment for expectation using a dynamic panel data specification.

The China Statistic Yearbook reports a measure for unit construction cost $c$, by dividing the value of buildings completed with the floor space of buildings completed reported by enterprises for real estate development. Although this information can only be found at the provincial level, most of the 35 cities come from different provinces so there is still enough cross-city variation in this variable.

The agriculture productivity $A$ is measured by agriculture GDP per rural capita, under the assumption that marginal revenue product of labor in agriculture is an increasing function of $A$. Agriculture GDP is from the China Statistic Yearbook for Regional Economy and rural population is from the Statistics of City and County Demographic.

It is not feasible to directly measure the total available land $L_{0}$ that is suitable for either agriculture production or residence without detailed geographic information such as in Saiz (2010). However, by definition, the administration area of a city is made of three parts: first, area that is not suitable for agriculture production or residence due to physical restriction; second, area that is already urban area or has been ready for urban development, which is known as constructed area; and finally, the unconstructed area that can potentially be converted from agriculture land to urban land. Since the first part is almost a constant, the third part, i.e., the total available land $L_{0}$, must be an increasing function of the difference between administration area and constructed area. City Statistics Yearbook reports information for both areas. 
Owing to the data limitations that the extra-budgetary and the non-budgetary revenue and expenditure at the city level are not publicly reported, the exact measure of budget deficit is not available. Following the literature, such as Deng, Gyourko and $\mathrm{Wu}$ (2012), this paper therefore proxies budget deficit $d$ as the difference between budgetary expenditure and budgetary revenue normalized by GDP. It means the unobservable off-budgetary deficit has to be treated as an error. Data for budgetary expenditure, revenue and GDP are all from the China Statistic Yearbook for Regional Economy.

Table 2 reports the summary statistics for all the variables discussed as above. Those variables in levels have been converted into 2003 constant yuan using city specific CPI. Log operation is applied to $p, l, a, g, y, N, c, A$ and $L_{0}$ in the regressions so that the corresponding coefficients have an elasticity interpretation.

\subsection{Results}

This section reports estimation results of the two structural equations for housing price (10) and land price (11), and the reduced-form housing price equation (12). ${ }^{7}$

Table 3 presents estimation results of land price structural equation (11). Since housing price $(p)$ and land price $(l)$ are simultaneously determined in equations (10) and (11), they are endogenous. Inconsistent fixed-effects results are included in Column 1 for comparison. To deal with the endogeneity issue, instruments for $(p)$ are used after within transformation. Column 2 (FEIV1) reports fixed-effects IV estimation using instruments $(a, g, y, N, s, i)$ (clean air, government education expenditure per student, disposable income per capita, total population, sex ratio and interest rate, respectively), which are exogenous in the housing price structural equation. The coefficient of budget deficit $(d)$ suggests that on average one percentage increase in local governments' budget deficit leads to a $12.6 \%$ increase in land price. This implies that holding other factors constant, if the budget deficit-to-GDP ratio of a city is one standard deviation higher than the average, its land price would be $29 \%$ higher than the average. The estimated housing price elasticity shows that $1 \%$ increase in housing price pulls up land price by $0.883 \%$. This large elasticity indicates that the increasing land price is mainly translated from the surge of housing prices. The firststage $F$ statistic is 52.25 , suggesting that the instruments used are statistically valid,

\footnotetext{
${ }^{7}$ Panel unit root tests have been conducted for both $(p)$ and $(l)$. Based on Levin-Lin-Chu and Im-Pesaran-Shin unit-root tests, no evidence supports that $l$ follows a unit root process. For housing price $p$, the testing results are conflicting. Levin-Lin-Chu test rejects the null hypothesis of unit root process, while Im-Pesaran-Shin test fails to reject the null. Since it is well known that housing price around the world do not follow a random walk (Case and Shiller, 1989) because of the downward stickiness, and the data set used here is a short panel with identification mainly from cross-city variation, the nonstationarity issue is less concerned.
} 
as predicted by equation (8) of the theoretical model. Using lagged housing prices $\left(p_{i, t-1}\right)$ as an instrument for $p_{i t}$, fixed-effects IV regression (Column 3, FEIV2) gives a similar estimate of the effect of budget deficit on land price, while the housing price elasticity drops to 0.782 .

Column 4 considers the case that $d_{i, t-1}$ is allowed to be endogenous. Agriculture GDP as a share of total GDP $\left(A R_{i, t-1}\right)$ is explored as an external instrument for $d_{i, t-1}$. Together with the instruments $(a, g, y, N, s, i)$ for $p_{i t}$, in this fixed-effects IV regression, the estimated effect of budget deficit on land prices increases to $16.5 \%$, and the housing price elasticity is nearly unchanged.

When year effects are included in Columns 5-8 of Table 3, the budget deficit coefficient slightly drops to $9.4 \%-11 \%$, but remains significant in most cases. The housing price elasticity decreases to $0.280-0.405$ and becomes statistically insignificant. ${ }^{8}$

The estimation results of housing price structural equation (10) are reported in Table $4 .{ }^{9}$ Column 1 presents fixed-effects estimates. Due to simultaneous causality, $l_{i t}$ is endogenous in housing price structural equation. $l_{i t}$ is instrumented by the excluded exogenous variables $\left(d_{i, t-1}, A_{i t}, L_{0, i t}\right)$ (budget deficit-to-GDP ratio, agriculture GDP per rural capita and total available land, respectively) in land price structural equation (11), and the corresponding fixed-effects IV estimates are reported in Column $2 .{ }^{10}$ The estimated land price elasticity is 0.008 and insignificant. The positive effects of clean air $(a)$ and local public goods $(g)$ on housing price that have been found in Zheng and Kahn (2008) for Beijing are also confirmed here for these 35 major cities. The elasticities of disposable income and total population $(y, N)$ are 0.698 and 0.386 , respectively. Consistent with Chow and Niu (2010) and Wang and Zhang (2013), such large magnitudes indicate the importance of income and population growth in driving housing prices. Finally, expected increase in housing price $\left(\pi^{Q}\right)$ also plays a significant role in pulling up housing prices. The coefficient implies that due to adaptive expectation, a one percentage increase in past housing price will lead to a 0.36 percentage increase in current housing price. ${ }^{11}$

Using a lagged value $\left(l_{i, t-1}\right)$ as an instrument for $l_{i t}$, fixed-effects IV in Column 3 gives a much bigger, but statistically insignificant, estimate of land price elasticity, 0.218. No strong evidence is found to explain the increasing housing prices by land

\footnotetext{
${ }^{8}$ All instruments are statistically significant in first-stage regressions of fixed-effects IV regression in Columns 3-4, 6-8.

${ }^{9}$ As suggested by Arellano (2003, p.61), since interest rate $i_{t}$ is a perfect linear combination of year dummies, year effects are not employed for housing price equations.

${ }^{10}$ The coefficient of $d_{i, t-1}$ is 0.102 and its $t$ ratio is 2.73 in the first-stage regression.

${ }^{11}$ In Columns $1-3, \pi_{i t}^{Q}$ is measured by the growth rate of $(\log )$ real housing price in the previous year, i.e., $\pi_{i t}^{Q}=p_{i, t-1}-p_{i, t-2}$. Since housing price data for the 35 major cities dated back to 1998 , we also experiment by calculating $\pi_{i t}^{Q}$ as the average real growth rate of housing price in the previous three years. Similar empirical results are obtained.
} 
price increase. Though the magnitudes of other coefficients are slightly different from those in Column 2, the same pattern remains: income, population and expectation have big effect on housing price, with estimates $0.483,0.472$ and 0.289 , respectively.

Instead of using past housing price growth as a direct measure, adaptive expectation may also be modelled by including lagged housing price levels in the housing price structural equation (10). This turns (10) into a dynamic panel data model. ${ }^{12}$ Arellano-Bond GMM estimates are reported. In addition to $p_{i, t-1}$ and $p_{i, t-2}, l,(l, g)$, and $(l, g, y, N)$ are treated as endogenous variables in GMM1, GMM2 and GMM3, respectively. In each model, other regressors are treated either as exogenous or predetermined. Across these 6 GMM estimation settings, land price elasticity ranges from 0.023 to 0.114 , supporting the finding of small effect of land price on housing price in the fixed-effects regressions (Columns 1-3). Together with a small and statistically insignificant estimate of the construction cost $(c)$, the regression results seem to indicate that supply side factors do not play a major role in determining the housing price, at least in this sample. In addition, the importance of clear air $(a)$, local public goods $(g)$ and disposable income $(y)$ is further confirmed here, but with smaller coefficients. Not surprisingly, as a measure of adaptive expectation, the coefficient for the first lag of the housing price $\left(p_{i, t-1}\right)$ turns to be large and significant. This also indicates the important effect of past housing price on current housing price. However, GMM estimates of population $(N)$ turn out insignificant with a much smaller magnitude, ranging from 0.047 to 0.224. A robustness check is implemented in Section 4.3 to investigate whether this is due to measurement errors in population. ${ }^{13}$

As one important component of the user cost, the effect of interest rate $(i)$ on housing price is pronounced: one percentage increase in interest rate leads to a $4 \%$ to $5 \%$ decrease in housing price in all specifications except Column 3. In addition, consistent with Wei, Zhang and Liu (2012), we find robust effect of sex ratio on housing price. One percentage of sex ratio raises housing price by $3 \%$ to $4 \%$.

Finally, to examine the overall effect of budget deficit on housing price, reducedform regression results for equation (12) are reported in Table 5. Column 1 reports the fixed-effects estimates, in which adaptive expectation $\pi_{i t}^{Q}=p_{i, t-1}-p_{i, t-2}$ is treated

\footnotetext{
${ }^{12}$ The model becomes:

$$
\begin{aligned}
p_{i t}= & \alpha_{0}+\rho_{1} p_{i, t-1}+\rho_{2} p_{i, t-2}+\alpha_{1} l_{i t}+\alpha_{2} a_{i t}+\alpha_{3} g_{i t}+\alpha_{4} y_{i t}+\alpha_{5} N_{i t} \\
& +\alpha_{6} s_{i t}+\alpha_{7} i_{t}+\alpha_{8} \pi_{i t}+\alpha_{10} c_{i t}+u_{i}^{p}+v_{i t}^{p} .
\end{aligned}
$$

${ }^{13}$ Arellano-Bond one-step GMM estimates with $t$ statistics based on robust standard errors are reported in Table 4. The two-step estimates yield similar coefficients. However, since the two-step GMM standard errors are downward biased, and the Windmeijer-corrected standard errors seem unreasonably big in this sample, two-step results are not included. The $p$-values of Sargan test in Table 4 are based on one-step GMM standard errors. The $p$-values of Arellano-Bond's m1, m2 tests based on robust standard errors are also reported. This is also the case in Tables 5 and 6 .
} 
as exogenous. Similarly, this expectation can be modelled by a dynamic panel data model. $^{14}$ Arellano-Bond GMM estimates with 2 lags are reported in GMM1. In GMM2 and GMM3, $(g)$ and $(g, y, N)$ are treated as endogenous variables, respectively. As in Table 4, in each model, other regressors are treated as either exogenous or predetermined. In all 7 sets of estimates, deficit-to-GDP ratio is insignificant and its coefficients are nearly 0, suggesting that the indirect effect of deficit-to-GDP ratio on housing price is negligible. No evidence is found that financing budget deficit by local governments is an important driving force of the recent soaring housing prices. ${ }^{15}$ This is consistent with the findings from the estimates of the two structural equations. Though high deficit-to-GDP ratio raises land price by a semi-elasticity from $9 \%$ to $17 \%$, land price contributes a small slice to housing price.

Except the additional regressors $\left(d, A, L_{0}\right)$ and construction cost $(c)$, the reducedform regression in Table 5 delivers similar message as the housing price structural equation results in Table 4. The four components of the user cost of housing capital, sex ratio $(s)$, interest rate $(i)$ and CPI growth rate $(\pi)$ and expected increase in housing price $\left(\pi^{Q}\right)$ all have the expected signs and most of them have significant effects across all alternative specifications. This implies that the growth of housing prices is mainly driven by the demand side factors, namely, change in amenities, income and the user cost of housing capital.

\subsection{Robustness Checks}

This section conducts three robustness checks. Table 6 summarizes the corresponding empirical findings by reporting the reduced-form housing price regressions. ${ }^{16}$ Each empirical exercise includes a fixed-effects regression where expectation is proxied by $\pi_{i t}^{Q}$, and a GMM regression with 2 lags.

The first robustness check excludes the 4 super cities (Beijing, Guangzhou, Shanghai and Shenzhen) from the sample. Since each of these cities has a population size over 10 million, a potential concern is that the land and housing markets in these cities

\footnotetext{
${ }^{14}$ The model becomes:

$$
\begin{aligned}
p_{i t}= & \theta_{0}+\delta_{1} p_{i, t-1}+\delta_{2} p_{i, t-2}+\theta_{1} d_{i, t-1}+\theta_{2} a_{i t}+\theta_{3} g_{i t}+\theta_{4} y_{i t}+\theta_{5} N_{i t}+\theta_{6} s_{i t}+\theta_{7} i_{t} \\
& +\theta_{8} \pi_{i t}+\theta_{10} c_{i t}+\theta_{11} A_{i t}+\theta_{12} L_{0, i t}+u_{i}+v_{i t} .
\end{aligned}
$$

${ }^{15}$ As pointed out by one referee, the impact of fiscal situation could last longer. To take this possibility into account, one-year lagged value $d_{t-1}$ is replaced with the average of three-year lagged values in regressions (11) and (12). In the housing price reduced-form regression, the magnitude of coefficients changes slightly. Same as in Table 5, budget deficit has little impact on housing price. This is also the case in the land price structural equation. The effect of budget deficit on land price increases a little. Results of new regression are available upon request.

${ }^{16}$ Estimation results of land price structural equation and housing price structural equation are not reported here due to space limitation, but are available upon request.
} 
could function differently from other large cities. As indicated by Columns 1 and 2 of Table 6 , the new results without these 4 cities nearly replicate those in Table 5 . For example, budget deficit contributes little to housing price. Amenities, disposable income and the user cost of housing capital are the main determinants of housing price. This implies that the main findings of this paper are not driven by the existence of the 4 super cities. In contrast, the economic mechanism described in the model applies to the 35 major cities across China.

The second robustness check employs an alternative measure of population. In Tables 4 and 5, there is no solid evidence that population growth leads to housing price increase. This is probably due to the imperfect measure of urban population. Since an accurate measure of urban population is not available, total population, the sum of agricultural population with hukou, non-agricultural population with hukou and ruralurban migrants without hukou, has been used in Tables 4 and 5. The urban population consists of the latter two parts, but the size of migrants could be poorly measured. To check the potential effect of measurement errors, an alternative measure of population, non-agricultural population, which is usually more accurately measured under the household registration system, is used here. Columns 3 and 4 of Table 6 deliver the same message as Table 5, except that the effect of non-agricultural population on housing price indeed gets more pronounced: the estimated elasticity ranges from 0.149 to 0.609 .

Last, one-period time lag is allowed for developers to build housing after bidding land. Specifically, for a given land quantity $L_{t-1}$, developers maximize their profit at period $t$, i.e., $p_{t} H_{t}-L_{t-1}\left(l_{t}+c_{t}\right)-c_{0 t}$, where $H_{t}=F\left(L_{t-1}\right)$. Under the assumption that developers could rationally expect housing price and construction cost for the next time period, the land demand (4) and housing supply (5) become

$$
L_{t-1}^{d}=L_{t-1}^{d}\left(p_{t}, l_{t-1}, c_{t}\right)
$$

and

$$
H_{t}^{s}=H_{t}^{s}\left(p_{t}, l_{t-1}, c_{t}\right) .
$$

Together with land supply (7) and housing demand (3), one can derive the following land price structural equation

$$
l_{i, t}=\beta_{0}+\beta_{1} p_{i, t+1}+\beta_{2} d_{i, t-1}+\beta_{3} c_{i, t+1}+\beta_{4} A_{i t}+\beta_{5} L_{0, i t}+u_{i}^{l}+v_{i t}^{l},
$$

housing price structural equation

$$
\begin{aligned}
p_{i t}= & \alpha_{0}+\alpha_{1} l_{i, t-1}+\alpha_{2} a_{i t}+\alpha_{3} g_{i t}+\alpha_{4} y_{i t}+\alpha_{5} N_{i t} \\
& +\alpha_{6} s_{i t}+\alpha_{7} i_{t}+\alpha_{8} \pi_{i t}+\alpha_{9} \pi_{i t}^{Q}+\alpha_{10} c_{i t}+u_{i}^{p}+v_{i t}^{p},
\end{aligned}
$$

and housing price reduced-form equation 


$$
\begin{aligned}
p_{i t}= & \theta_{0}+\theta_{1} d_{i, t-2}+\theta_{2} a_{i t}+\theta_{3} g_{i t}+\theta_{4} y_{i t}+\theta_{5} N_{i t}+\theta_{6} s_{i t}+\theta_{7} i_{t} \\
& +\theta_{8} \pi_{i t}+\theta_{9} \pi_{i t}^{Q}+\theta_{10} c_{i t}+\theta_{11} A_{i, t-1}+\theta_{12} L_{0, i t-1}+u_{i}+v_{i t} .
\end{aligned}
$$

Notice that since there is one-period lag in both $l$ of (16) and $d$ of (15), $d$ is now two-period lagged in (17). Columns 5 and 6 of Table 6 report the estimation results: The budget deficit has no significant positive effect on housing price if not negative, while other findings of Table 5 are still observed.

\section{Conclusion}

Through the analysis on the interrelated housing and land markets, this paper tests a popular hypothesis that local governments' budget deficit has caused a surge in housing prices in China. The empirical results confirm a positive effect of budget deficit on land prices but deny budget deficit as a driving force of housing prices. Demand side factors, such as amenities, income, and in particular, the user cost of housing capital have been found to be the main determinants of housing prices. Meanwhile, rapid growth of housing prices is found to be the most important explanatory variable in land price appreciation. Given the fact that many local governments have heavily relied on land lease revenue to meet their budget deficit, it is not surprising why frequent price regulations ordered by the central government aiming to curb housing price inflation haven't achieved the goal. As pointed out by Xu (2011), fiscal decentralization has been regarded as an important institution for the spectacular performance of Chinese economy. However, the very same institution, may also have created side effects.

There are two major limitations in this paper that could be improved in future research. First, our theoretical model assumes all the variables except housing and land prices to be exogenous. Although our empirical exercises have allowed for the potential endogeneity of income, population, government revenue and expenditure, a more appealing treatment calls for a theoretical work in a general equilibrium framework where all such variables are endogenously determined. Second, the conclusion of the paper is subject to the availability and quality of data, especially on key variables such as housing prices, land prices and budget deficit. Deng, Gyourko and Wu (2012) have made an important start on constructing constant quality housing and land prices using micro-level data. Nevertheless, the framework derived in this paper is generally useful for future research once more and better data are available. 


\section{References}

[1] Albouy, David (2009), "What are Cities Worth? Land Rents, Local Productivity, and the Capitalization of Amenity Values," NBER Working Paper No. 14981.

[2] Arellano, Manuel (2003), Panel Data Econometrics, Oxford University Press: Advanced Texts in Econometrics.

[3] Cai, Hongbin, J. Vernon Henderson, and Qinghua Zhang (2012), "China's Land Market Auctions: Evidence of Corruption," Rand Journal of Economics, forthcoming.

[4] Case, Karl E. and Robert J. Shiller (1987), "Prices of Single Family Homes Since 1970: New Indexes for Four Cities," New England Economic Review, 3: 45-56.

[5] Case, Karl E. and Robert J. Shiller (1988), "The Behavior of Home Buyers in Boom and Post-Boom Markets," New England Economic Review, 2: 9-46.

[6] Case, Karl E. and Robert J. Shiller (1989), "The Efficiency of the Market for Single-Family Homes," American Economic Review, 79(1): 9-46.

[7] Chow, Gregory C. and Linlin Niu (2010), "Demand and Supply for Residential Housing in Urban China," in Joyce Man (ed.), China's Housing Reform and Outcomes, Cambridge, MA: Lincoln Institute Press.

[8] Deng, Yongheng, Joseph Gyourko and Jing Wu (2012), "Land and House Price Measurement in China," NBER Working Paper No. 18403.

[9] Deng, Yongheng, Randall Morck, Jing Wu and Bernard Yeung (2011), "Monetary and Fiscal Stimuli, Ownership Structure, and China's Housing Market," NBER Working Paper No. 16871.

[10] Garriga, Carlos, Yang Tang, and Ping Wang (2013), "Rural-urban Migration, Structural Change and Housing Price Hike in China," working paper.

[11] Himmelberg, Charles, Chris Mayer, and Todd Sinai (2005), "Assessing High House Prices: Bubbles, Fundamentals and Misperceptions," Journal of Economic Perspectives, 19(4): 67-92.

[12] Jia, Junxue, Qingwang Guo and Jing Zhang (2014), "Fiscal decentralization and local expenditure policy in China," China Economic Review, 28: 107-122.

[13] Kuang, Weida (2010), "Expectation, Speculation and Urban Housing Price Volatility in China," Economic Research Journal, 9: 67-78.

[14] Kung, James., Chenggang Xu and Feizhou Zhou (2011), "From Industrialization to Urbanization: The Social Consequences of Changing Fiscal Incentives on Local Governments' Behavior," in Joseph E. Stiglitz (ed.), Institutional Design for China's Evolving Market Economy, Columbia University Press.

[15] Liang, Yunfang and Tiemei Gao (2007), "Empirical Analysis on Real Estate Price Fluctuation in Different Provinces of China," Economic Research Journal, 8: 134142.

[16] Mills, Edwin S. (1967), "An Aggregative Model of Resource Allocation in a Metropolitan Area," American Economic Review, 57(2): 197-210.

[17] Oates, Wallace E. (1969), "The Effects of Property Taxes and Local Public Spending on Property Values: An Empirical Study of Tax Capitalization and the Tiebout Hypothesis," Journal of Political Economy, 77(6): 958-970. 
[18] Poterba, James M. (1984), "Tax subsidies to owner-occupied housing: an asset market approach," Quarterly Journal of Economics 94(4): 729-752.

[19] Poterba, James M. (1991), "House Price Dynamics: The Role of Tax Policy and Demography," Brookings Papers on Economic Activity, 2: 143-183.

[20] Potepan, Michael J. (1996), "Explaining Intermetropolitan Variation in Housing Prices, Rents and Land Prices," Real Estate Economics, 24(2): 219-245.

[21] Ren, Yu, Cong Xiong, Yufei Yuan (2012), "House price bubbles in China," China Economic Review, 23: 786-800.

[22] Saiz, Albert (2010), "The Geographic Determinants of Housing Supply," Quarterly Journal of Economics, 125(3): 1253-1296.

[23] Tiebout, Charles M. (1956), "A Pure Theory of Local Expenditure," Journal of Political Economy, 64: 416-424.

[24] Wang, Shing-Yi (2011), "State Misallocation and Housing Prices: Theory and Evidence from China," American Economic Review, 101: 2081-2107.

[25] Wang, Zhi and Qinghua Zhang (2013), "Fundamentals in China's Housing Market," Brown University working paper.

[26] Wei, Shang-Jin, Xiaobo Zhang and Yin Liu (2012), "Status Competition and Housing Prices," NBER Working Paper No. 18000.

[27] Wu, Jing, Joseph Gyourko and Yongheng Deng (2012), "Evaluating Conditions in Major Chinese Housing Market," Regional Science and Urban Economics, 42: 531-543.

[28] Wu, Jing, Yongheng Deng and Hongyu Liu (2013), "House Price Index Construction in the Nascent Housing Market: The Case of China," The Journal of Real Estate Finance and Economics, forthcoming.

[29] Xu, Chenggang (2011), "The Fundamental Institutions of China's Reforms and Development," Journal of Economic Literature, 49(4): 1076-1151.

[30] Zheng, Siqi and Matthew E. Kahn (2008), "Land and Residential Property Markets in a Booming Economy: New Evidence from Beijing," Journal of Urban Economics, 63: 743-757.

[31] Zheng, Siqi, Matthew E. Kahn and Hongyu Liu (2010), "Towards a System of Open Cities in China: Home Prices, FDI Flows and Air Quality in 35 Major Cities," Regional Science and Urban Economics, 40: 1-10.

[32] Zhou, Jingkui (2011), "Uncertainty and housing tenure choice by household types: Evidence from China," China Economic Review, 22(3): 408-427. 
Figure 1 Average Real Residential Housing Prices in 35 Major Chinese Cities (2003 Yuan)

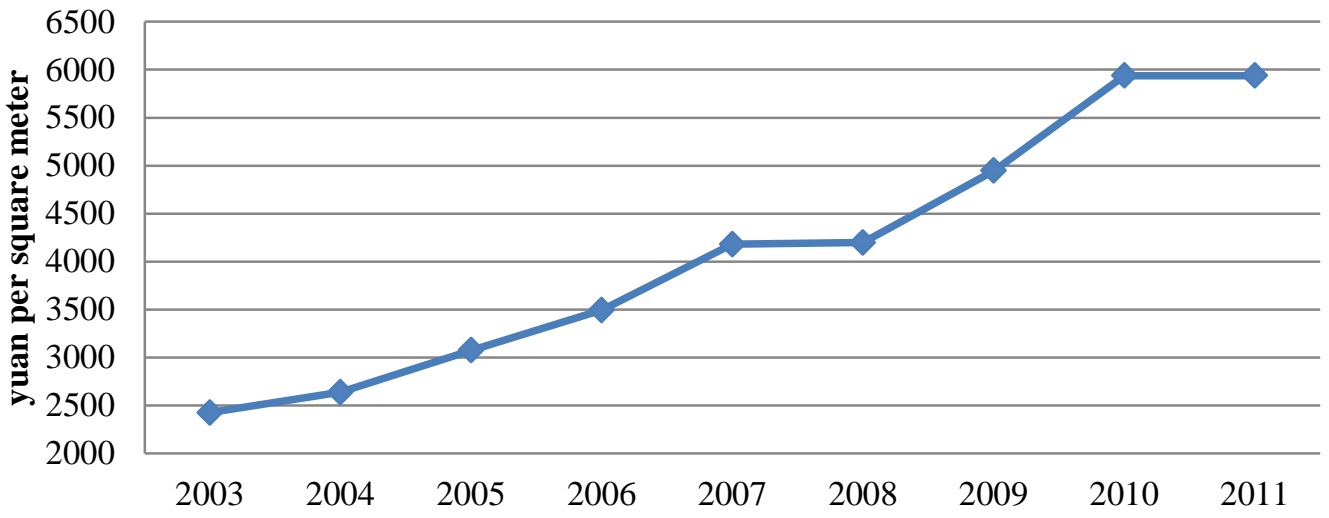

Data sources: China Real Estate Statistic Book 2004-2012.

Figure 2 Average Real Land Prices in 35 Major Chinese Cities (2003 Yuan)

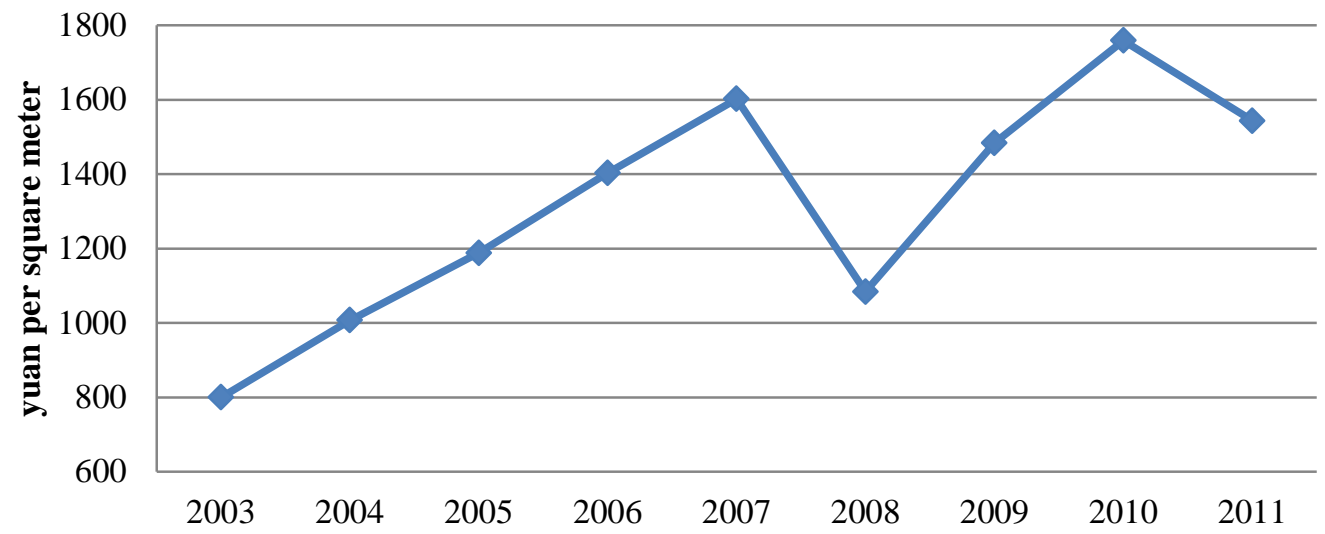

Data sources: China Land and Resource Almanac 2004-2012.

Figure 3 The Shares of Budgetary Deficit and Land Transferring Fee to Budgetary Revenue in 35 Major Chinese Cities

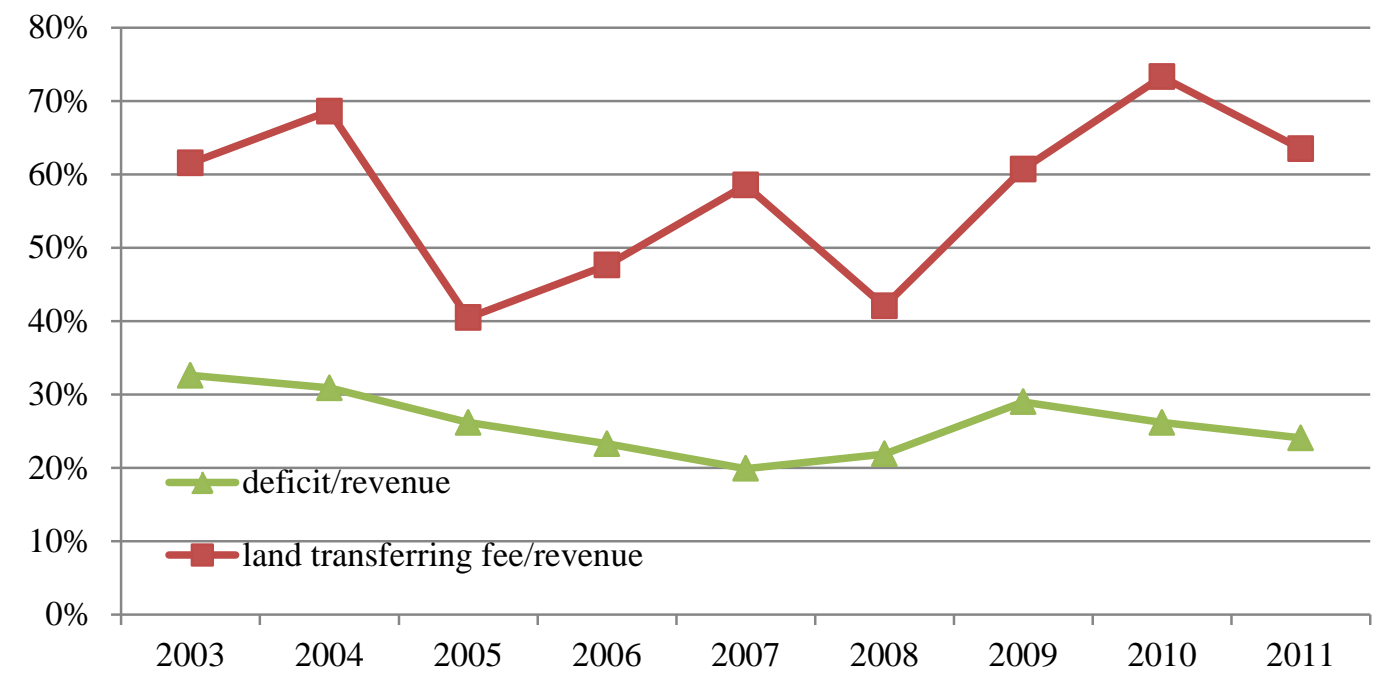

Data sources: China Statistic Yearbook for Regional Economy 2004-2012. 
Table 1 Fiscal Reform, Budget Deficit and Land Transferring Fee

\begin{tabular}{rrrrrrrr}
\hline \hline year & $(1)$ & $(2)$ & $(3)$ & $(4)$ & $(5)$ & $(6)$ & $(7)$ \\
\hline 1993 & 78.00 & 71.70 & 34.99 & -0.17 & -0.20 & 15.07 & n.a. \\
1994 & 44.30 & 69.70 & 68.32 & 3.58 & -0.19 & 28.11 & n.a. \\
1995 & 47.80 & 70.80 & 69.97 & 3.03 & -0.18 & 13.00 & 0.63 \\
1996 & 50.60 & 72.90 & 78.62 & 2.87 & -0.20 & 9.32 & 0.52 \\
1997 & 51.10 & 72.60 & 60.60 & 2.88 & -0.18 & 9.68 & 0.52 \\
1998 & 50.50 & 71.10 & 58.55 & 3.19 & -0.17 & 10.19 & 0.52 \\
1999 & 48.90 & 68.50 & 56.39 & 3.84 & -0.20 & 9.19 & 0.46 \\
2000 & 47.80 & 65.30 & 55.87 & 3.99 & -0.26 & 9.30 & 0.43 \\
2001 & 47.60 & 69.50 & 50.66 & 4.86 & -0.33 & 16.61 & 0.40 \\
2002 & 45.00 & 69.30 & 47.43 & 5.62 & -0.39 & 28.38 & 0.38 \\
2003 & 45.40 & 69.90 & 42.51 & 5.43 & -0.27 & 55.04 & 0.40 \\
2004 & 45.10 & 72.30 & 36.56 & 5.44 & -0.24 & 53.91 & 0.37 \\
2005 & 47.70 & 74.10 & 33.83 & 5.38 & -0.19 & 38.71 & 0.32 \\
2006 & 47.20 & 75.30 & 32.46 & 5.61 & -0.21 & 44.13 & 0.30 \\
2007 & 45.90 & 77.00 & 26.68 & 5.56 & -0.24 & 51.83 & 0.32 \\
2008 & 46.70 & 78.70 & 21.38 & 6.56 & -0.06 & 35.81 & 0.25 \\
2009 & 47.60 & 80.00 & 18.60 & 8.34 & -0.09 & 52.69 & 0.29 \\
2010 & 48.90 & 82.21 & 13.28 & 8.29 & -0.01 & 67.62 & 0.25 \\
2011 & 50.60 & 84.90 & n.a. & 8.50 & n.a. & 61.14 & 0.23 \\
\hline \hline
\end{tabular}

Notes: (1) Data sources:

China Statistical Yearbook 1994-2012, China Land and Resources Almanac 1998-2012, China Land Yearbook 1995-1997.

(2) Definition for data in each column

Column (1): local governments budgetary revenue /national government budgetary revenue $\times 100 \%$

Column (2): local governments budgetary expenditure/national government budgetary expenditure $\times 100 \%$

Column (3): local governments extra-budgetary revenue/logcal governments budgetary revenue $\times 100 \%$

Column (4): (local government budgetary expenditure - budgetary revenue)/GDP $\times 100 \%$

Column (5): (local government extra-budgetary expenditure - extra-budgetary revenue)/GDP $\times 100 \%$

Column (6): land transferring fee/local governments budgetary revenue $\times 100 \%$

Column (7): provincial Gini coefficient of the ratio of land transferring fee to local governments budgetary revenue 
Table 2 Summary Statistics of Variables

\begin{tabular}{|c|c|c|c|c|c|c|}
\hline Symbol & Definition & Unit & Mean & Std. D. & $\begin{array}{l}\text { Form in } \\
\text { regression }\end{array}$ & Data sources \\
\hline$p$ & average real residential housing prices & thousand yuan/sq. m. & 4.092 & 2.608 & $\log$ & China Real Estate Statistic Book \\
\hline$l$ & real land prices = land transferring fee/area via auctions & thousand yuan/sq. m. & 1.319 & 1.210 & $\log$ & China Land and Resource Almanac \\
\hline$a$ & $\mathrm{SO}_{2}$ density $=\mathrm{SO}_{2}$ emission/administration area & $\mathrm{kg} / \mathrm{sq} . \mathrm{km}$ & 10.62 & 9.82 & $-\log$ & City Statistic Yearbook \\
\hline$g$ & real government expenditure on education per student & thousand yuan & 0.430 & 0.463 & $\log$ & China Statistic Yearbook for Regional Economy \\
\hline$y$ & real urban disposable income per capita & 10 thousand yuan & 1.446 & 0.519 & $\log$ & China Statistic Yearbook for Regional Economy \\
\hline$s$ & sex ratio $=($ male $/$ female -1$) \times 100 \%$ & $\%$ & 4.37 & 3.31 & $\%$ & Statistics of City and County Demographic \\
\hline$i$ & nominal interest rate for 5-year deposit & $\%$ & 4.04 & 0.97 & $\%$ & Bank of China \\
\hline$\pi$ & growth rate of CPI & $\%$ & 2.99 & 2.19 & $\%$ & City Statistics Yearbook \\
\hline$\pi^{Q}$ & growth rate of real housing price & $100 \%$ & 0.12 & 0.10 & $100 \%$ & calculated from $p$ and $\pi$ \\
\hline$c$ & real construction cost & thousand yuan/sq. m. & 1.483 & 0.503 & $\log$ & China Statistic Yearbook \\
\hline$A$ & real agriculture GDP per rural capita & thousand yuan & 1.613 & 8.157 & $\log$ & $\begin{array}{l}\text { China Statistic Yearbook for Regional Economy, } \\
\text { Statistics of City and County Demographic }\end{array}$ \\
\hline$d$ & budget deficit=(budgetary expenditure-revenue)/GDP×100\% & $\%$ & 2.92 & 2.29 & $\%$ & China Statistic Yearbook for Regional Economy \\
\hline$A R$ & agriculture GDP share=agriculture GDP/total GDP×100\% & $\%$ & 5.36 & 3.54 & $\%$ & China Statistic Yearbook for Regional Economy \\
\hline
\end{tabular}


Table 3 Estimation Results of Land Price Structural Equation

Dependent variable: Land price $l$

\begin{tabular}{|c|c|c|c|c|c|c|c|c|}
\hline Independent variables: & $\begin{array}{l}\mathrm{FE} \\
(1)\end{array}$ & $\begin{array}{c}\text { FEIV1 } \\
\text { (2) }\end{array}$ & $\begin{array}{c}\text { FEIV2 } \\
\text { (3) }\end{array}$ & $\begin{array}{c}\text { FEIV3 } \\
(4)\end{array}$ & $\begin{array}{l}\text { FE } \\
\text { (5) }\end{array}$ & $\begin{array}{c}\text { FEIV1 } \\
(6)\end{array}$ & $\begin{array}{c}\text { FEIV2 } \\
(7)\end{array}$ & $\begin{array}{c}\text { FEIV3 } \\
\text { (8) }\end{array}$ \\
\hline Housing price $p$ & $\begin{array}{c}0.853^{* * *} \\
(5.50)\end{array}$ & $\begin{array}{c}0.883^{* * *} \\
(4.31)\end{array}$ & $\begin{array}{c}0.782^{* * *} \\
(4.13)\end{array}$ & $\begin{array}{c}0.889 * * * \\
(4.33)\end{array}$ & $\begin{array}{c}0.309 \\
(1.09)\end{array}$ & $\begin{array}{l}0.405 \\
(0.55)\end{array}$ & $\begin{array}{l}0.280 \\
(0.54)\end{array}$ & $\begin{array}{l}0.346 \\
(0.45)\end{array}$ \\
\hline (lagged) Deficit-to-GDP ratio $d$ & $\begin{array}{c}0.126 * * * \\
(3.92)\end{array}$ & $\begin{array}{c}0.127 * * * \\
(3.92)\end{array}$ & $\begin{array}{c}0.124^{* * * *} \\
(3.84)\end{array}$ & $\begin{array}{c}0.165^{* *} \\
(1.98)\end{array}$ & $\begin{array}{c}0.095^{* * * *} \\
(2.82)\end{array}$ & $\begin{array}{c}0.098 * * \\
(2.48)\end{array}$ & $\begin{array}{c}0.094^{* * * *} \\
(2.61)\end{array}$ & $\begin{array}{l}0.110 \\
(1.35)\end{array}$ \\
\hline Construction cost $c$ & $\begin{array}{c}-0.864 * * * \\
(-3.36)\end{array}$ & $\begin{array}{c}-0.903 * * * \\
(-2.91)\end{array}$ & $\begin{array}{c}-0.773 * * * \\
(-2.64)\end{array}$ & $\begin{array}{c}-0.985 * * * \\
(-2.74)\end{array}$ & $\begin{array}{c}-1.168 * * * \\
(-3.86)\end{array}$ & $\begin{array}{c}-1.163 * * * \\
(-3.82)\end{array}$ & $\begin{array}{c}-1.169 * * * \\
(-3.86)\end{array}$ & $\begin{array}{c}-1.184 * * * \\
(-3.64)\end{array}$ \\
\hline Agricultural GDP per capita $A$ & $\begin{array}{l}0.072 \\
(1.13)\end{array}$ & $\begin{array}{l}0.072 \\
(1.13)\end{array}$ & $\begin{array}{l}0.072 \\
(1.12)\end{array}$ & $\begin{array}{l}0.080 \\
(1.21)\end{array}$ & $\begin{array}{c}0.081 \\
(1.28)\end{array}$ & $\begin{array}{l}0.080 \\
(1.26)\end{array}$ & $\begin{array}{l}0.081 \\
(1.28)\end{array}$ & $\begin{array}{c}0.083 \\
(1.27)\end{array}$ \\
\hline Available land $L_{0}$ & $\begin{array}{l}-0.662 \\
(-0.94)\end{array}$ & $\begin{array}{l}-0.666 \\
(-0.95)\end{array}$ & $\begin{array}{l}-0.652 \\
(-0.93)\end{array}$ & $\begin{array}{l}-0.746 \\
(-1.03)\end{array}$ & $\begin{array}{l}-0.533 \\
(-0.77)\end{array}$ & $\begin{array}{l}-0.538 \\
(-0.77)\end{array}$ & $\begin{array}{l}-0.531 \\
(-0.77)\end{array}$ & $\begin{array}{l}-0.562 \\
(-0.79)\end{array}$ \\
\hline Year effects & No & No & No & No & Yes & Yes & Yes & Yes \\
\hline $\begin{array}{l}\text { Overall } R^{2} \\
\text { Number of observations }\end{array}$ & $\begin{array}{l}0.21 \\
280\end{array}$ & $\begin{array}{l}0.21 \\
280 \\
\end{array}$ & $\begin{array}{l}0.20 \\
280 \\
\end{array}$ & $\begin{array}{l}0.17 \\
280 \\
\end{array}$ & $\begin{array}{l}0.04 \\
280\end{array}$ & $\begin{array}{l}0.07 \\
280 \\
\end{array}$ & $\begin{array}{l}0.03 \\
280 \\
\end{array}$ & $\begin{array}{l}0.04 \\
280 \\
\end{array}$ \\
\hline $\begin{array}{l}\text { Endogenous variables } \\
\text { Instruments }\end{array}$ & & $\begin{array}{c}p \\
a, g, y, N, s, i\end{array}$ & $\begin{array}{c}p \\
p_{t-1}\end{array}$ & $\begin{array}{c}p, d_{t-1} \\
a, g, y, N, s, i, A R_{t-1}\end{array}$ & & $\begin{array}{c}p \\
a, g, y, N, s, i\end{array}$ & $\begin{array}{c}p \\
p_{t-1}\end{array}$ & $\begin{array}{c}p, d_{t-1} \\
a, g, y, N, s, i, A R_{t-1}\end{array}$ \\
\hline
\end{tabular}

Notes: $1 . t$ statistics are reported in parentheses. The stars, * ** and *** indicate the significance level at $10 \%, 5 \%$ and $1 \%$, respectively.

2. FE denotes fixed-effects regression. FEIV means fixed-effects IV estimation using instruments specified in different columns.

3. For the definition, unit of variables and data sources, please refer to Table 2. 
Table 4 Estimation Results of Housing Price Structural Equation

Dependent variable: Housing price $p$

\begin{tabular}{|c|c|c|c|c|c|c|c|c|c|}
\hline \multirow[t]{2}{*}{ Independent variables: } & \multirow{2}{*}{$\begin{array}{l}\mathrm{FE} \\
(1)\end{array}$} & \multirow{2}{*}{$\begin{array}{c}\text { FEIV1 } \\
\text { (2) }\end{array}$} & \multirow{2}{*}{$\begin{array}{c}\text { FEIV2 } \\
\text { (3) }\end{array}$} & \multicolumn{2}{|c|}{$\underline{\text { GMM1 }}$} & \multicolumn{2}{|c|}{$\underline{\text { GMM2 }}$} & \multicolumn{2}{|c|}{$\underline{\text { GMM3 }}$} \\
\hline & & & & (4) & (5) & (6) & (7) & (8) & (9) \\
\hline \multirow[t]{2}{*}{ Land price $l$} & $0.028 *$ & 0.008 & 0.218 & $0.114^{* * *}$ & $0.024 *$ & $0.064 * *$ & $0.024 *$ & $0.037^{*}$ & 0.023 \\
\hline & (1.68) & $(0.11)$ & $(0.88)$ & $(2.82)$ & $(1.71)$ & $(2.16)$ & (1.68) & (1.83) & (1.59) \\
\hline \multirow[t]{2}{*}{ Clean air $a$} & $0.116^{* * *}$ & $0.114^{* * *}$ & $0.131^{* * *}$ & $0.096 * * *$ & $0.077 * * *$ & $0.084 * * *$ & $0.077 * * *$ & $0.085 * * *$ & $0.077 * * *$ \\
\hline & $(4.64)$ & $(4.42)$ & $(3.45)$ & $(4.09)$ & (3.91) & (3.54) & (3.89) & $(4.82)$ & (3.93) \\
\hline \multirow[t]{2}{*}{ Government edu. exp. per student $g$} & $0.162 * * *$ & $0.166^{* * *}$ & $0.121^{*}$ & 0.055 & $0.092 * *$ & 0.071 & $0.091^{* *}$ & 0.076 & $0.095 * *$ \\
\hline & $(4.16)$ & $(3.90)$ & $(1.65)$ & $(1.27)$ & $(2.52)$ & $(1.33)$ & $(2.50)$ & $(1.59)$ & $(2.46)$ \\
\hline \multirow[t]{2}{*}{ Disposable income per capita $y$} & $0.678 * * *$ & $0.698 * * *$ & 0.483 & $0.423 * * *$ & $0.375 * * *$ & $0.338 * * *$ & $0.381 * * *$ & $0.385 * * *$ & $0.371 * * *$ \\
\hline & $(5.67)$ & $(4.83)$ & (1.63) & $(3.27)$ & $(3.46)$ & $(2.72)$ & $(3.50)$ & $(3.06)$ & $(3.26)$ \\
\hline \multirow[t]{2}{*}{ Total population $N$} & $0.394^{* *}$ & $0.386 * *$ & $0.472 * *$ & 0.224 & 0.091 & 0.098 & 0.090 & 0.047 & 0.073 \\
\hline & $(2.43)$ & $(2.32)$ & $(2.03)$ & $(0.55)$ & $(0.64)$ & $(0.40)$ & $(0.63)$ & $(0.29)$ & $(0.51)$ \\
\hline \multirow[t]{2}{*}{ Construction cost $c$} & 0.097 & 0.082 & 0.250 & 0.040 & 0.044 & $0.116 *$ & 0.044 & 0.074 & 0.044 \\
\hline & $(1.20)$ & $(0.80)$ & $(1.12)$ & $(0.57)$ & $(0.74)$ & (1.83) & $(0.73)$ & $(1.23)$ & $(0.73)$ \\
\hline \multirow[t]{2}{*}{ Sex ratio $s$} & $0.038 * *$ & $0.039 * *$ & 0.030 & $0.042^{* *}$ & $0.036 * *$ & $0.032 *$ & $0.036 * *$ & $0.028 *$ & $0.037 * *$ \\
\hline & $(2.52)$ & $(2.51)$ & $(1.36)$ & $(2.44)$ & (2.33) & (1.93) & $(2.32)$ & $(1.78)$ & $(2.38)$ \\
\hline \multirow[t]{2}{*}{ Interest rate $i$} & $-0.040 * *$ & $-0.044 *$ & -0.000 & $-0.042 * * *$ & $-0.054 * * *$ & $-0.046 * * *$ & $-0.054 * * *$ & $-0.049 * * *$ & $-0.055 * * *$ \\
\hline & $(-2.43)$ & $(-1.89)$ & $(0.00)$ & $(-3.01)$ & $(-4.54)$ & $(-3.58)$ & $(-4.53)$ & $(-3.68)$ & $(-4.53)$ \\
\hline \multirow[t]{2}{*}{ CPI growth rate $\pi$} & 0.003 & 0.004 & -0.002 & 0.007 & 0.006 & 0.006 & 0.006 & 0.006 & 0.006 \\
\hline & $(0.50)$ & 0.55 & $(-0.21)$ & $(1.37)$ & $(1.30)$ & $(1.28)$ & $(1.32)$ & $(1.21)$ & $(1.33)$ \\
\hline Housing price growth rate $\pi^{Q}$ & $\begin{array}{c}0.353^{* * *} \\
(4.59)\end{array}$ & $\begin{array}{c}0.360 * * * \\
(4.41)\end{array}$ & $\begin{array}{c}0.289 * * \\
(2.22)\end{array}$ & & & & & & \\
\hline \multirow[t]{2}{*}{ Lagged housing price at $t-1 p_{t-1}$} & & & & $0.440 * * *$ & $0.565^{* * *}$ & $0.513 * * *$ & $0.562^{* * *}$ & $0.526 * * *$ & $0.564 * * *$ \\
\hline & & & & $(4.34)$ & $(12.68)$ & $(6.74)$ & $(12.37)$ & $(8.88)$ & $(12.16)$ \\
\hline \multirow[t]{2}{*}{ Lagged housing price at $t-2 p_{t-2}$} & & & & 0.029 & $-0.069 *$ & -0.030 & $-0.069 *$ & -0.048 & $-0.065 *$ \\
\hline & & & & $(0.54)$ & $(-1.75)$ & $(-0.67)$ & $(-1.74)$ & $(-1.08)$ & $(-1.65)$ \\
\hline Overall $R^{2}$ & 0.62 & 0.61 & 0.63 & & & & & & \\
\hline Number of observations & 245 & 245 & 245 & 210 & 210 & 210 & 210 & 210 & 210 \\
\hline Other endogenous regressors & & $l$ & $l$ & $l$ & $l$ & $l, g$ & $l, g$ & $l, g, y, N$ & $l, g, y, N$ \\
\hline Instruments: & & $d_{t-1}, A, L_{0}$ & $l_{t-1}$ & GMM type & GMM type & GMM type & GMM type & GMM type & GMM type \\
\hline Other regressors & & & & exogenous & predetermined & exogenous & predetermined & exogenous & predetermined \\
\hline m1 (p-value) & & & & 0.00 & 0.00 & 0.00 & 0.00 & 0.00 & 0.00 \\
\hline m2 (p-value) & & & & 0.01 & 0.08 & 0.04 & 0.08 & 0.05 & 0.07 \\
\hline Sargan test (p-value) & & & & 0.00 & 0.38 & 0.00 & 0.34 & 0.02 & 0.29 \\
\hline
\end{tabular}

Notes: $1 . t$ statistics are reported in parentheses. The stars, *, ** and *** indicate the significance level at $10 \%, 5 \%$ and $1 \%$, respectively.

2. FE denotes fixed-effects regression. FEIV means fixed-effects IV estimation using instruments specified in different columns. GMM stands for Arellano-Bond one-step GMM estimates.

3. For the definition, unit of variables and data sources, please refer to Table 2. 25 
Table 5 Estimation Results of Housing Price Reduced-form Equation

Dependent variable: Housing price $p$

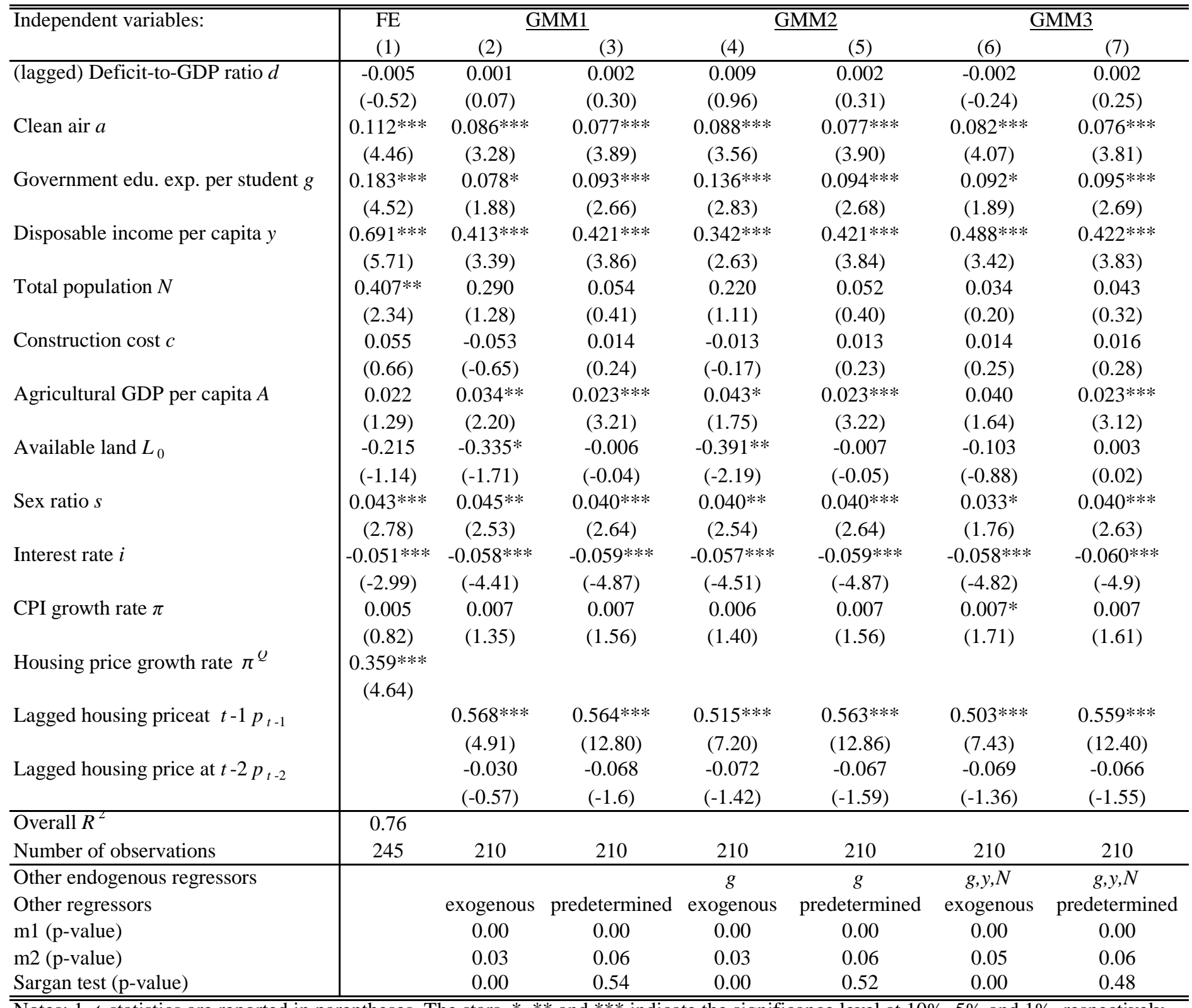

Notes: $1 . t$ statistics are reported in parentheses. The stars, *, ** and *** indicate the significance level at $10 \%, 5 \%$ and $1 \%$, respectively.

2. FE denotes fixed-effects regression. GMM stands for Arellano-Bond one-step GMM estimates.

3. For the definition, unit of variables and data sources, please refer to Table 2. 
Table 6 Robustness Checks: Estimation Results of Housing Price Reduced-form Equation

Dependent variable: Housing price $p$

\begin{tabular}{|c|c|c|c|c|c|c|}
\hline \multirow[b]{2}{*}{ Independent variables: } & \multicolumn{2}{|c|}{ excluding 4 super cities } & \multicolumn{2}{|c|}{ non-agriculture population } & \multicolumn{2}{|c|}{ time-to-build } \\
\hline & $\begin{array}{l}\mathrm{FE} \\
(1)\end{array}$ & $\begin{array}{l}\text { GMM } \\
\text { (2) }\end{array}$ & $\begin{array}{l}\mathrm{FE} \\
(3)\end{array}$ & $\begin{array}{l}\text { GMM } \\
\text { (4) }\end{array}$ & $\begin{array}{l}\mathrm{FE} \\
(5)\end{array}$ & $\begin{array}{l}\text { GMM } \\
(6)\end{array}$ \\
\hline $\begin{array}{r}\text { (lagged) Deficit-to-GDP ratio } d \text { for (1)-(4) } \\
\text { (2-period lagged) } d \text { for (5), (6) }\end{array}$ & $\begin{array}{l}-0.003 \\
(-0.31)\end{array}$ & $\begin{array}{l}0.002 \\
(0.31)\end{array}$ & $\begin{array}{l}-0.004 \\
(-0.45)\end{array}$ & $\begin{array}{l}0.002 \\
(0.30)\end{array}$ & $\begin{array}{c}-0.030 * * * \\
(-3.14)\end{array}$ & $\begin{array}{l}-0.015 \\
(-1.38)\end{array}$ \\
\hline Clean air $a$ & $\begin{array}{l}0.090 * * * \\
(3.46)\end{array}$ & $\begin{array}{l}0.067 * * * \\
(2.71)\end{array}$ & $\begin{array}{l}0.091^{* * *} \\
(3.61)\end{array}$ & $\begin{array}{l}0.073^{* * *} \\
(3.48)\end{array}$ & $\begin{array}{l}0.097 * * * \\
(3.85)\end{array}$ & $\begin{array}{l}0.066^{* * *} \\
(3.46)\end{array}$ \\
\hline Government edu. exp. per student $g$ & $\begin{array}{l}0.193^{* * * *} \\
(4.73)\end{array}$ & $\begin{array}{l}0.113^{* * *} \\
(3.42)\end{array}$ & $\begin{array}{l}0.190 * * * \\
(4.81)\end{array}$ & $\begin{array}{l}0.098 * * * \\
(2.72)\end{array}$ & $\begin{array}{l}0.216^{* * *} \\
(5.05)\end{array}$ & $\begin{array}{l}0.119 * * * \\
(3.39)\end{array}$ \\
\hline Disposable income per capita $y$ & $\begin{array}{l}0.649 * * * \\
(5.41)\end{array}$ & $\begin{array}{l}0.374 * * * \\
(3.47)\end{array}$ & $\begin{array}{l}0.672 * * * \\
(5.72)\end{array}$ & $\begin{array}{l}0.414^{* * *} \\
(3.79)\end{array}$ & $\begin{array}{l}0.616^{* * *} \\
(5.02)\end{array}$ & $\begin{array}{l}0.382^{* * *} \\
(3.95)\end{array}$ \\
\hline $\begin{array}{l}\text { Total population } N \\
\text { Non-agricultural population for (3), (4) }\end{array}$ & $\begin{array}{l}0.070 \\
(0.37)\end{array}$ & $\begin{array}{l}-0.090 \\
(-0.66)\end{array}$ & $\begin{array}{l}0.609 * * * \\
(3.72)\end{array}$ & $\begin{array}{l}0.149 \\
(1.07)\end{array}$ & $\begin{array}{l}0.293^{*} \\
(1.78)\end{array}$ & $\begin{array}{l}0.058 \\
(0.45)\end{array}$ \\
\hline Construction cost $c$ & $\begin{array}{l}0.093 \\
(1.06)\end{array}$ & $\begin{array}{l}0.013 \\
(0.20)\end{array}$ & $\begin{array}{l}0.013 \\
(0.16)\end{array}$ & $\begin{array}{l}0.008 \\
(0.13)\end{array}$ & $\begin{array}{l}0.113 \\
(1.40)\end{array}$ & $\begin{array}{l}0.060 \\
(0.96)\end{array}$ \\
\hline $\begin{array}{l}\text { Agricultural GDP per capita } A \\
\text { (lagged) } A \text { for (5), (6) }\end{array}$ & $\begin{array}{l}0.020 \\
(1.21)\end{array}$ & $\begin{array}{l}0.023 * * * \\
(3.44)\end{array}$ & $\begin{array}{l}-0.027 \\
(-1.22)\end{array}$ & $\begin{array}{l}0.011 \\
(0.70)\end{array}$ & $\begin{array}{l}-0.016 \\
(-0.94)\end{array}$ & $\begin{array}{l}-0.017 \\
(-1.13)\end{array}$ \\
\hline $\begin{array}{l}\text { Available land } L_{0} \quad \text { (lagged) } L_{0} \text { for (5), (6) }\end{array}$ & $\begin{array}{l}-0.022 \\
(-0.12)\end{array}$ & $\begin{array}{l}0.065 \\
(0.53)\end{array}$ & $\begin{array}{l}-0.223 \\
(-1.24)\end{array}$ & $\begin{array}{l}-0.015 \\
(-0.11)\end{array}$ & $\begin{array}{l}0.146 \\
(0.54)\end{array}$ & $\begin{array}{l}0.151 \\
(0.77)\end{array}$ \\
\hline Sex ratio $s$ & $\begin{array}{c}0.035^{* *} \\
(2.35)\end{array}$ & $\begin{array}{l}0.037 * * \\
(2.46)\end{array}$ & $\begin{array}{c}0.045^{* * * *} \\
(3.02)\end{array}$ & $\begin{array}{c}0.041^{* * *} \\
(2.69)\end{array}$ & $\begin{array}{c}0.038 * * \\
(2.53)\end{array}$ & $\begin{array}{c}0.037 * * \\
(2.42)\end{array}$ \\
\hline Interest rate $i$ & $\begin{array}{c}-0.059 * * * \\
(-3.34)\end{array}$ & $\begin{array}{c}-0.068^{* * *} \\
(-5.33)\end{array}$ & $\begin{array}{c}-0.061 * * * \\
(-3.65)\end{array}$ & $\begin{array}{c}-0.061^{* * *} \\
(-5.17)\end{array}$ & $\begin{array}{c}-0.055 * * * \\
(-3.34)\end{array}$ & $\begin{array}{c}-0.062^{* * *} \\
(-4.79)\end{array}$ \\
\hline CPI growth rate $\pi$ & $\begin{array}{l}0.009 \\
(1.36)\end{array}$ & $\begin{array}{c}0.010^{* *} \\
(2.19)\end{array}$ & $\begin{array}{l}0.006 \\
(1.06)\end{array}$ & $\begin{array}{l}0.007 \\
(1.63)\end{array}$ & $\begin{array}{l}0.005 \\
(0.90)\end{array}$ & $\begin{array}{l}0.007 \\
(1.57)\end{array}$ \\
\hline Housing price growth rate $\pi^{\mathrm{u}}$ & $\begin{array}{c}0.349 * * * \\
(4.32)\end{array}$ & & $\begin{array}{c}0.37 * * * \\
(4.97)\end{array}$ & & $\begin{array}{c}0.378 * * * \\
(4.96)\end{array}$ & \\
\hline Lagged housing priceat $t-1 p_{t-1}$ & & $\begin{array}{c}0.554^{* * *} \\
(11.40)\end{array}$ & & $\begin{array}{c}0.562^{* * *} \\
(12.97)\end{array}$ & & $\begin{array}{c}0.568 * * * \\
(12.32)\end{array}$ \\
\hline Lagged housing price at $t-2 p_{t-2}$ & & $\begin{array}{l}-0.050 \\
(-1.04)\end{array}$ & & $\begin{array}{l}-0.079 \\
(-1.63)\end{array}$ & & $\begin{array}{c}-0.098 * * \\
(-2.52)\end{array}$ \\
\hline Overall $R^{2}$ & 0.64 & & 0.71 & & 0.53 & \\
\hline Number of observations & 217 & 186 & 245 & 210 & 245 & 210 \\
\hline m1 (p-value) & & 0.00 & & 0.00 & & 0.00 \\
\hline m2 (p-value) & & 0.11 & & 0.08 & & 0.08 \\
\hline Sargan test (p-value) & & 0.45 & & 0.52 & & 0.52 \\
\hline
\end{tabular}

Notes: $1 . t$ statistics are reported in parentheses. The stars, *, ** and *** indicate the significance level at $10 \%$, 5\% and $1 \%$, respectively.

2. FE denotes fixed-effects regression. GMM stands for Arellano-Bond one-step GMM estimates.

3. For the definition, unit of variables and data sources, please refer to Table 2. 